\title{
Neoliberalism and the Emergence of Private Sustainability Initiatives: The Case of the Brazilian Cattle Value Chain
}

\author{
Stéphane Guéneau* \\ Centre de coopération internationale en recherche agronomique pour le développement (Cirad), UMR Moisa, \\ Montpellier, France
}

\begin{abstract}
Recent studies have examined the political significance of the emergence of governmental initiatives to develop sustainability standards for agricultural commodities in the transition economies. Yet, few studies have examined how neoliberal ideas influence the governance of value chains in the agri-food sector of these countries. This paper's goal is to explore the changing role of the state in sustainable cattle value chain governance in Brazil, through a methodology of participant observation of the Brazilian Roundtable on Sustainable Livestock (GTPS). The results describe the technologies used to govern the cattle value chain, which involves a private action controlled at a distance by the state that is aimed at making products acceptable on world markets. This neoliberal governmentality does not address some crucial sustainability issues of the cattle value chain. The findings call for an extension of evaluation methods so that more attention can be devoted to alternative cattle production systems. Copyright (c) 2018 John Wiley \& Sons, Ltd and ERP Environment
\end{abstract}

Received 28 November 2016; revised 4 August 2017; accepted 18 August 2017

Keywords: neoliberal governmentality; private governance; hybrid governance; value chain; livestock industry; deforestation

\section{Introduction}

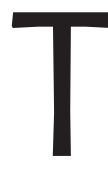

HE ROUNDTABLES, STEERING COUNCILS AND OTHER MULTI-STAKEHOLDER INITIATIVES (MSIS) TO CREATE SUSTAINABLE PRODUCTION standards have multiplied since the I990s. The aim of these initiatives is to regulate the environmental and social impacts of the activities of firms in a growing number of agro-industrial sectors (coffee, cocoa, palm oil, soybean, biofuels, forest products, sugar cane, cotton, meat etc.) (Cheyns et al., 20I7).

Much of the literature uses institutionalist approaches to show that these private initiatives aimed at standardizing sustainable development are the most legitimate forms of governance of agri-food value chains (Bernstein and Cashore, 2007; Schouten and Glasbergen, 20II). In this theoretical approach, the emergence of transnational private governance instruments is often explained by the need to fill gaps in public policy in a context of weak states

*Correspondence to: Stéphane Guéneau, Centre de coopération internationale en recherche agronomique pour le développement (Cirad), UMR Moisa, Montpellier, France.

E-mail: stephane.gueneau@cirad.fr 
(Marx and Cuypers, 20I0). Private regulatory initiatives are thus meant to overcome the limited capabilities of importing countries (in the global North) to impose policies on their suppliers (in the global South) in order to regulate the environmental and social effects of the international trade in commodities (Vermeulen, 20Io). Thus, private governance can be viewed as a functionalist response to the regulatory failures resulting from the processes of globalization.

However, this theoretical perspective has been challenged by two main research streams. On the one hand, a large quantity of literature focuses on the political dimension of these private governance initiatives (Cheyns and Riisgaard, 20I4; Loconto and Fouilleux, 20I4). The formulation of sustainability standards is an opportunity for the exercise of power, where some categories of private actors try to push their own interests, often to the detriment of the most disadvantaged local actors. Some studies suggest paying more attention to the horizontal dimension instead of to the vertical dimension of value chain governance, i.e., to consider the interplay between actors who are not directly involved in the chain but may have strong influence over governance structures such as MSIs and their decisions (Neilson and Pritchard, 20I0). Others have examined the role of ideas in understanding ideational power in value chains, through analyses of the way narratives are used to promote specific interests (Nelson and Tallontire, 20I4). Nevertheless, apart from some rare exceptions (Djama et al., 20II), few studies have examined how neoliberal ideas influence the implementation of MSIs, despite the normative power of this ideological framework on the conduct of human activities and their alignment with market principles and competition. As Graz and Nölke (2008) note (p. 239), 'transnational private governance is not only supported by neoliberalism, but can also be viewed as its supporter, by contributing to its stabilization'.

On the other hand, a significant body of the literature on global governance has evolved towards a more nuanced analysis of the 'privatization of governance'. In particular, a series of recent studies suggests that states are far from being sidelined. First, scholars report the recent emergence of a new wave of public norms in the transition economies, such as state-driven schemes for certifying the legality of timber and various governmental initiatives to develop or impose sustainability standards on palm oil, soybean and other agricultural commodities (Bartley, 20I4; Schouten and Bitzer, 20I5). Following these findings, some scholars highlight the pendulum-like movement from government to governance and back again (Giessen et al., 20I6). While it is often reported that private regulatory initiatives can step in to undertake functions that governments of the global South cannot or do not want to undertake themselves, these recent studies show that the role of transition economies is far from being limited to that of standards takers. This movement can be interpreted as a kind of public re-appropriation of private regulations in order to reinstate private governance in the public sphere (Hospes, 20I4; Schouten and Bitzer, 20I5) - even though such attempts at public re-appropriation are not new. They have already taken place in the past in several countries of the global South, as shown by the multiplication of several national forestry certification schemes in the I990s and 2000 s (Guéneau, 2009). Despite these findings, scholars who have recently been interested in this dynamic point out the under-researched role of the state in the global South in the institutionalization of private governance (Glasbergen, 2016).

Second, private standards and other instruments of transnational private governance do not emerge in opposition to public authority. As Bartley (20I4) says, the 'notion of "bypassing the State" has turned out to be mythical'. Research has repeatedly shown that the institutionalization of private initiatives requires a certain degree of public action, both at the formulation/development stage and at the implementation stage (Giessen et al., 20I6; Gulbrandsen, 20I4; Vermeulen and Kok, 20I2). Recent studies that have focused on public-private interactions in the institutionalization of new forms of governance categorize the interaction between private and public regulation as complements or substitutes (Lambin et al., 20I4), most often to determine whether public interventions enable the scaling up of private programs (Alves-Pinto et al., 20I5). Other scholars believe that private and public actors are categories that are jostling for power (Giessen et al., 20I6). When private initiatives and public actions are analyzed through the notion of co-regulation, the focus is on the dynamics of mutual reinforcement of state policies and non-state initiatives in order to see whether it reduces or expands the space for global private authority (Bartley, 20I4; Gulbrandsen, 20I4). Yet, these studies do not analyze the state's ways of acting, or whether the public role in private value chain governance means a shift is taking place back to the classical forms of control that are specific to governments.

Building on existing literature on the changing role of emerging states in sustainable value chain governance, the purpose of this paper is to address the interactions between public and private actors and institutions within the 
processes of institutionalization of new forms of governance. The central focus of this paper is on analyzing how neoliberal ideas and discourses have influenced the governance of sustainability of the cattle value chain in Brazil. What neoliberal techniques have been used to create the compromises between the actors involved in the governance of the cattle value chain? What are the consequences for sustainability of this neoliberal orientation?

\section{Neoliberal Governmentality}

In order to understand the interactions between public and private actors and the institutionalization of new forms of neoliberal governance of the cattle value chain in Brazil, we will turn to earlier research that has relied on Michel Foucault's work on the notion of governmentality. According to Lascoumes (2004), Foucault's theoretical contribution on governmentality pertains to his way of theorizing the state. Foucault disregards debates on the nature of the state and its legitimacy to concentrate his thinking on the concrete practices of government.

Foucault defines the concept of governmentality as 'The ensemble formed by the institutions, procedures, analyses and reflections, the calculations and tactics that allow the exercise of this very specific albeit complex form of power, which has as its target population, as its principal form of knowledge political economy, and as its essential technical means apparatuses of security' (Foucault, 2004b).

The concept of governmentality therefore refers to a specific and concrete way of exercising power. In its broad acceptance, governmentality is generally defined as the 'conduct of conducts' (Foucault, 2004a), i.e., as a means of imposing standards of behavior on individuals and groups in a non-disciplinary manner (Jeanpierre, 2006). Governmentality reflects the transition from forms of power that operate through obedience and punishment to forms of 'government at a distance' (Miller and Rose, I990), i.e. the implementation of technologies of government that lead individuals or groups to govern themselves. According to Foucault, individuals and groups are no longer passive objects that merely 'receive' top-down public policies. In the Foucauldian perspective, they are autonomous subjects, able to organize themselves in order to perform functions of governance (Sending and Neumann, 2006).

Although Foucault's work clearly rejects any centralizing and authoritarian conception of power, his theories are far from ignoring the state, which remains a central actor, especially in the analysis of neoliberalism. From the perspective of governmentality, Foucault perceives neoliberalism as an 'art of government' that implies state interventions and often strong corrective actions. Unlike liberal approaches that consider the market as a natural selfregulating phenomenon and mandate passive state policies, neoliberal approaches consider that the state must play a powerful interventionist role (Fouilleux and Daviron, 20I0). However, state intervention has to be directed primarily to foster competition and create the conditions necessary to promote the market economy (Brown, 2003). Neoliberalism therefore requires public action in order to promote competition in all areas of social life, in marked opposition to public policies that aim to correct the possible negative effects of competition (Jeanpierre, 2006).

Political rationalities are another important dimension of neoliberal governmentality. A political rationality is defined by a set of ideas, principles and knowledge that frame an object of government (Djama et al., 20II). These two dimensions of neoliberal governmentality - political rationalities and technology of government - complement each other. The former refers to the selection of what should be the object of concern so that it can be a matter of public action, and to the manner of dealing with it. The latter makes it possible to create actions undertaken by autonomous and responsible individuals in order to address the issue (the object of government) and, in this way, achieve the objectives of the governing authorities.

For the past several decades, changes in public policy have resulted from the rise of neoliberal rationales through the introduction of numerous market-based instruments, such as the development of tradable pollution rights that aim to combat climate change. Neoliberalism relies on a toolbox that also contains instruments such as contracts, audits and certification, benchmarking, and consultative and participatory procedures (Fouilleux and Daviron, 20I0). To apply the neoliberal doctrine means to govern according to the model of the enterprise. It also means putting consumer interests first, including by placing the responsibility of social regulation on their shoulders, because they are the very people who promote competition (Guthman, 2007).

Neoliberal governmentality can thus be understood as an art of government whose purpose is to impose the market as a normative logic for society. It is a matter of institutionalizing the market economy as a fundamental 
principle of the organization of society. According to Foucault, neoliberal governmentality is expressed by the fact that it is necessary 'to govern for the market rather than to govern because of the market' (Foucault, 2004a).

In this article, we apply this theory of neoliberal governmentality to the public action that the Brazilian state has deployed in the face of the emergence of private governance arrangements. We do so through the lens of the fundamental elements that characterize liberal governmentality, by using the following analytical framework. First, we will analyze the nature of action 'at a distance' of the neoliberal state: what are the normative frameworks put in place by the state in order to allow the actors of the sector to organize themselves on their own to participate in the market? Then we will analyze the nature of the instruments used: do they originate from a market logic, from an entrepreneurial management of public affairs? Finally, we will analyze the domain of application of the state's neoliberal action (neoliberal political rationality): what are the principles that guide action and are they in line with market rationality?

\section{Methodology}

We employed a qualitative case-study design for the cattle value chain in Brazil. We chose to study the Brazilian beef sector for two reasons. First, the Brazilian beef sector is one of the sectors that attracts the most complaints for its impacts on the environment, in particular as regards deforestation. Several private regulatory sustainability initiatives involving NGOs, retailers, agri-food companies, financial institutions and cattle-rancher associations have emerged in recent years to address these environmental challenges. The beef industry is also the subject of numerous public policy measures aimed at improving the sector's sustainability.

Second, since 20I4, our research institution enjoys the status of observer member in the Brazilian Roundtable on Sustainable Livestock (GTPS). Formally constituted in 2009, the GTPS is composed of representatives from the different segments that make up the beef value chain in Brazil including, among many others, the major meat processing companies (JBS, Marfrig, Minerva), some of the big retailers and restaurants (Carrefour, Walmart, McDonald's) and some of the most influential NGOs (WWF, The Nature Conservancy). GTPS's overall mission can be summarized as the development of instruments that promote sustainable beef production.

This position inside the GTPS allowed us to adopt a research methodology based largely on participant observation, a classical qualitative method of ethnographic research. Participant observation aims to understand and interpret the meanings and experiences of a group through exchanges between participants who are in their own environment and through observations of their discourses and behaviors. In addition to direct observation, participant observation includes various techniques such as the analysis of informal 'corridor conversations', in-depth informal unstructured interviews, examination of statements produced by the group, and results of on-line and faceto-face sub-group meetings (Jorgensen, I989). We attended several events, including the GTPS General Assembly and various thematic seminars on the intensification of production systems, on livestock and climate change, and on sustainable farming practices. We also participated in few thematic groups (scientific and political committees) and events organized on the margins of the GTPS.

This methodology has been complemented by a series of nine semi-structured interviews of key informant stakeholders who are not part of the GTPS. These interviews were mainly conducted in Brasilia, where the headquarters of the ministries and departments in charge of agricultural and environmental matters are located. We have also conducted an extensive, in-depth documentary analysis of the Brazilian cattle value chain, including the gray literature, devoting particular attention to a qualitative analysis of the information exchanged within the networks interested in the sustainability of the Brazilian cattle value chain (e.g. newsletters, websites and campaigns).

\section{The Transformation of the Brazilian Cattle Value Chain: Challenges of Sustainability}

The Brazilian cattle value chain encompasses a variety of products including live animals and various processed goods, of which the most produced and valuable are leather and beef, the latter accounting for about two-thirds 
of the export value (Walker et al., 2013). The Brazilian beef-cattle industry has grown exponentially since the midI970s. Brazil is now the second largest producer of beef in the world, accounting for about I8\% of world production. The Brazilian cattle herd is the world's largest commercial herd. It exceeded 2I5 million head in 20I5, after growing by more than $40 \%$ in Io years (IBGE, 20I7). Even though approximately $80 \%$ of its production is sold domestically, Brazil remains a major player on the world market. For more than a decade, the country has remained one of the top three exporters of beef in the world.

In its upstream segment, the value chain includes a large number of ranches that play the role of initial breeders. The cattle are sold to larger fattening farms that, in turn, supply slaughterhouses. In the I990s and early 2000 , livestock farming was based on easy and unregulated access to land, especially in the Brazilian Amazon. Productivity was low and distribution was organized mainly through local butcher shops.

Even though livestock farming still remains a predominantly extensive activity, the situation has changed progressively over more than a decade with the professionalization of the entire industry, both upstream (genetic improvement, nutrition, health safety) and downstream (slaughter, preservation, processing, distribution). Formerly dominant, self-consumption, direct sales at livestock farms, and local informal trading channels have become increasingly less important in comparison with new trade channels set up for supplying large urban areas in the south of the country and international markets.

Nowadays, the industry is primarily represented by three major groups (Marfrig, JBS and Minerva), which slaughter, process and trade the bulk of Brazilian meat. These large companies already accounted for over one-third of the sector's sales in 2008 (Schlesinger, 2010). The JBS Corporation, with its headquarters in São Paulo, dominates the global meat industry. It has subsidiaries all over the world and is the largest beef processor in the United States.

The phenomenon of concentration has also been reinforced in the downstream segment: large supermarkets have gradually replaced retail butchers, who, for many decades, made up the most widespread meat distribution system in Brazil. At present, three large transnational supermarket chains control a large part of the distribution of meat products in Brazil.

The recent growth of the cattle industry has taken place mainly in Amazonian states, where livestock accounts for almost $38 \%$ of the country's total herd, as compared with just I8\% in I990 (IBGE, 20I7). In the mid- to late 2000 , the cattle industry began to be confronted by challenges of sustainability that have since profoundly altered its organization. Many interviewed stakeholders and authors point out that the trigger for these changes was the publication of a report by Greenpeace accusing the Brazilian livestock sector of being the main cause of deforestation in the Amazon. Although this issue remains highly controversial due to the complexity of determining the causes of deforestation (e.g. land speculation and land settlement policies), the most recent research shows that pastures represent about two-thirds of the cleared areas in the Brazilian Amazon (Coutinho et al., 20I3).

Therefore, in various Brazilian discussion forums, the issue of sustainability is mainly approached through the problem of the deforestation of the Amazon. This is especially true for the GTPS, which has aligned itself with a 'zero deforestation' position: 'After undertaking a commitment to zero deforestation, with the creation of conditions and forms of compensation to make it feasible, GTPS and its members are concentrating their efforts on developing tools and mechanisms involving monitoring, tracking, production criteria, purchase and financing, and economic incentives to promote sustainable beef (Bastos, 2013). The solution to reduce the environmental impacts is linked to improved productivity and the need for intensification of production. This conception helps the largest meatpacker companies remove hurdles to market access in a cost-effective way.

\section{Governance Instruments that Address the Sustainability of the Cattle Value Chain}

During the early phases of the Action Plan for Prevention and Control of Deforestation in the Amazon (PPCDAM), launched in 2004, public policies to combat deforestation were primarily based on command-and-control instruments: creation of protected areas, land regulations, police operations against environmental crimes, and punishment. Federal action in this regard took a significant turn in 2007 with the issuing of a presidential decree calling on the Ministry of the Environment to publish an annual blacklist of municipalities most affected by 
deforestation in the Amazon and to impose public policy measures focused on these areas. In 2008, the 36 worst affected municipalities were covered by enhanced IBAMA (the Brazilian Institute for the Environment) control measures.

The federal government adopted measures to restrict access to credit for the farmers in blacklisted municipalities. One of the conditions necessary for the removal of a municipality from the deforestation blacklist is the requirement to implement the Rural Property Registry (Portuguese acronym CAR). This instrument delineates the boundaries of forest areas on the plots, in order to monitor the landholder's compliance with the Forestry Code. Since credit is one of the main drivers of economic activity, producers in the Amazon state of Pará were especially affected by this measure, a situation that even led to violent conflicts between farmers and local authorities. Faced with this situation, local multi-stakeholder initiatives such as the 'Green Municipalities' program were created and then generalized throughout Pará state. This program is designed to help affected municipalities ensure compliance with legislation.

In addition, federal public prosecutors and leading environmental NGOs have increased pressure on the main meat distribution chains. In 2009, the federal public attorney's office introduced the Term of Adjustment of Conduct (TAC). This measure has made the withdrawal of lawsuits by the federal public prosecutors against slaughterhouses and meatpacking companies conditional on an obligation by these entities to verify that their suppliers are not in contravention of the law. This measure has been reinforced by the registration of non-compliant properties identified by IBAMA in a public list of embargoed areas.

This wide range of public measures is in line with Brazil's commitments to international climate negotiations. In 2009, the federal government set a target of reducing annual Amazon deforestation by $80 \%$ by 2020 , compared with a baseline historical average annual loss of I9 $500 \mathrm{~km}^{2}$ between I996 and 2005 . Following this commitment, the government launched its low-carbon agriculture plan (ABC Plan). The flagship measure of this plan is making soft loans to producers conditional on improvements in sustainable production - largely linked to the intensification of livestock production systems.

Following the release of the Greenpeace report and the call for a boycott of beef from ranches that do not respect the law, the largest four slaughterhouse companies in Brazil have signed a 'livestock agreement' with Greenpeace, also known as the 'zero-deforestation agreement'. This agreement aims to set up a sustainable value chain through a commitment by the companies to avoid buying animals from plots deforested after the entry into force of the agreement, or those that originate from properties that do not have a CAR. Slaughterhouses have begun to exclude ranches that do not comply with these measures from their value chains, thus making it clear to the farmers that access to the market depends on the fight against deforestation.

A study conducted in Pará state shows that at the end of $201396 \%$ of transactions between JBS slaughterhouses and their suppliers involved registered properties, whereas prior to the agreement only $2 \%$ of them had CAR (Gibbs et al., 20I6). However, the effectiveness of the agreement remains contested because the suppliers of slaughterhouses can buy animals that have initially been raised on ranches that do not comply with the law. Thus, the companies that have signed the TAC - not all have done so - are still exposed to the risks associated with deforestation, as they do not control indirect suppliers and the possibility of fraud remains high. This is the reason why some companies have contracted with independent auditors in order to monitor the legality of their purchases. Verifying the legality and the absence of deforestation along the entire value chain would require full traceability, an undertaking that would be exceedingly complex given the large number of breeders scattered across the Amazon region.

Public research has been strongly mobilized to guide the Brazilian livestock industry towards sustainability. In line with the orientation of sustainability efforts within the GTPS, research by the public agricultural research body Embrapa focuses to a large extent on the recovery of degraded pastures and on intensification of cattle breeding, and their respective roles in the fight against deforestation and climate change. Embrapa has also launched a sustainable agriculture and livestock practices program, which has been implemented in hundreds of farms across the country and serves as a reference for the development of standards and practical techniques.

The major industrial groups, Marfrig, Minerva and JBS, have all implemented their own sustainability policies. For example, the Marfrig Club is a code of conduct based on three main criteria (environmental welfare, social welfare and animal welfare). Cattle ranchers who supply the group are audited and are classified into five categories according to their degree of compliance with the code: beginner, bronze, silver, gold and platinum. Farmers who have succeeded in reaching the highest category are rewarded through a premium on the purchase price. Other large 
companies have also made their commitments clear. An example of one such company is the Brazilian division of Arcos Dorados, the franchise of McDonald's in Latin America. It has recently announced its commitment to purchase meat only from sustainable ranches for its network of restaurants. The large supermarkets also have their own buying policies. For example, the Walmart Group has pledged to no longer finance, purchase and distribute livestock products from farms recognized as being illegal, contributing to deforestation, or using slave labor.

Through the Brazilian Supermarket Association (Portuguese acronym ABRAS), retailers attempted to set up a cattle certification system in 2009, whose technical design was entrusted to the Swiss auditing company SGS. This initiative failed due to the lack of participation by organizations representing cattle ranchers. Nevertheless, the SAN (Sustainable Agriculture Network) cattle program, an international third-party sustainability certification initiative, was launched in 2010 under the auspices of Imaflora, an NGO that represents the Rainforest Alliance in Brazil.

In a context of increasing prospects for Brazilian beef production, the transition to the sustainability of the sector is being mainly driven by the GTPS through a conscious intensification of livestock farming: producing more at lower cost on a smaller area, and thus avoiding deforestation resulting from extensive livestock farming. Part of the activity of the GTPS has concerned the translation of this definition of the sustainable cattle industry into sustainability standards (criteria and indicators).

The GTPS has gradually asserted itself as one of the pivots of reflection on the sustainability of the cattle industry. It plays a networking role, bringing together various actors around a common strategic agenda that includes developing mechanisms for monitoring value chains, being the point of interaction between the private sector and the government, disseminating good practices, and the scaling-up of pilot projects that focus on sustainable intensification and recovery of degraded lands. A memorandum of understanding between the GTPS and the federal government was signed in 2012 in order to achieve the goal of recovering I5 million hectares of degraded land within the ABC plan. The ministry of agriculture and livestock has supported some GTPS-labeled pilot projects. Even though it is not officially endorsed by the Brazilian government, the GTPS enjoys strong support from the public authorities. Several ministry representatives acknowledge that the GTPS is now a key interlocutor of the private sector and an essential partner of the government in addressing sustainability issues in the cattle value chain.

To summarize, this whole narrative tells us that the state first defined a general objective of fighting deforestation mainly through production intensification. Then a general instruction was issued to the downstream actors of the value chain - meatpackers and retailers - to clean up their purchases, but leaving it up to them to organize themselves internally in order to achieve this objective. All value chain stakeholders have to develop their own initiatives and implement concrete measures to comply with the public regulation framework (cf. Table I).

\section{Discussion}

\section{The Neoliberal Bias}

This research has attempted to analyze the role of emerging countries in sustainable value chain governance through the lens of neoliberal governmentality theory. Our results show that sustainability governance of the Brazilian cattle value chain is far from operating without any state intervention. These findings reinforce our earlier work on the crucial role of the state in the governance of sustainable forestry value chains in Amazonia (Guéneau and Drigo, 20I3), as well as other research on state intervention in the governance of sustainable value chains of various agri-food products in other countries (Hospes, 20I4; Schouten and Bitzer, 20I5). From these first results, we suggest that it is necessary to go beyond analytical frameworks based on strict demarcations between the public and the private sectors, a recommendation that is in line with other studies that highlight the hybrid nature of governance (Ponte and Daugbjerg, 20I5).

In addition, our research clearly indicates that the technology of government employed in order to govern the Brazilian cattle value chain is part of a neoliberal governmentality, complementing previous research on this topic (Djama et al., 20II). The Brazilian state is acting increasingly through persuasive measures, instead of coercive ones. The example of the conditions under which landowners are allowed to exit from IBAMA's list of embargoed areas shows that, in accordance with the neoliberal principles, the state plays the role of a regulator rather than a 
Type of public intervention that

frames the behavior of the

stakeholders within the cattle value chain

Publication of a blacklist of municipalities affected by deforestation. Restriction of access to credit for farmers in blacklisted municipalities.

Formulation of a Term of Adjustment of Conduct (TAC).

ABC Plan
Neoliberal rationality

Removal from the blacklist needs a self-organization of the stakeholders at the local level in order to meet the legal requirements and to self-control illegal activities.

Governance by contract: suspension of court proceedings for illegal deforestation in exchange for voluntary commitment by the private actors to organize themselves in order to comply with the Forestry Code.

Focus on a narrowing conception of sustainability (the Amazon deforestation issue) that 'fits' the global market requirements. Technical solutions adapted to the most capitalized actors (intensification of livestock farming systems is the key) are supported by public research.
Type of neoliberal instrument implemented by the actors within the value chain, following the public intervention

Green municipalities: concertation of the stakeholders at the local level to implement the landholders' compliance with the Forestry Code.

Zero-deforestation agreements.

Corporate social and environmental responsibility policies of meatpacker industries, supermarket companies and other large purchasing industries.

Third-party certification.

Formulation of standards of best practices that buttress this conception of sustainability in a multi-stakeholder forum (the CTPS).

Implementation of GTPS-labeled pilot projects on intensification of livestock farming systems.

Table 1. Interventions by the Brazilian State and their relation to neoliberal governmentality

prescriber. Public and private actions are being coordinated in order to achieve an objective that fits the neoliberal agenda: restoring confidence by making the products 'politically acceptable' on world markets. This technology of government has led to the emergence of a variety of instruments in line with the neoliberal doctrine, as reported earlier by other scholars (Guthman, 2008): zero-deforestation agreements, standards of best practices and stakeholder participation within the GTPS, and the internationally recognized SAN sustainability certification system.

A likely explanation for this neoliberal governmentality is that the interests of agro-industrial exporters are strongly represented in the Brazilian Congress and within successive governments, whether right wing or left wing. The challenge these governments have faced is to imagine subtle forms of resistance to internationally imposed standards, which stick to the neoliberal discourse and instruments that are promoted internationally. Hospes (20I4) suggests that governance instruments have been launched by governments and producer associations in Brazil in order to challenge sustainability interventions from the North. Our results complement this picture, showing that the sustainability challenge has been re-appropriated at the national level though private action - controlled at a distance by the state - aimed at making the market work without any social and environmental interference. Additional work is required to analyze whether this neoliberal orientation is specific to the Brazilian context, notably through studies to be carried out in other exporting countries where a public re-appropriation of private sustainability standards has already been observed (e.g. Malaysia, Indonesia).

\section{Consequences for Sustainability}

Our findings show that the neoliberal governmentality of the Brazilian cattle value chain includes cognitive work in order to put a certain conception of the public problem on the agenda. Since market-oriented cattle business is assumed to be most at risk from a lack of sustainability, public action addresses the issue of sustainability in a very one-sided way: it aims to tackle the problem of deforestation in order to insert the most capitalized players into international markets.

As far as this crucial environmental problem is concerned, this strategy has had some success. Combined with other policy interventions (see Nepstad et al., 20I4, for an overview of policies against deforestation in the Brazilian Amazon), it has led to a decrease in the rate of deforestation by $80 \%$ in a decade. Yet, these results are very uncertain 
and unconsolidated, as shown by the rise in deforestation rates in 2015 and 2016 . This reversal seems to be linked to the major political changes that have occurred recently in Brazil. The change of government that followed the impeachment of President Dilma Rousseff has signaled a consolidation of the political forces that represent agribusiness interests within Congress (the bancada ruralista), which are in favor of policies clearly oriented more towards agricultural expansion than towards biodiversity conservation. Several unilateral executive decrees (medidas provisórias), which have immediate force of law, have been enacted recently in order to downsize various protected areas in Legal Amazon. Another possible explanation for the return of deforestation is that the focus of concern in the sector is currently mainly on health issues, following the recent scandal of tainted meat related to the fight against corruption (operação carne fraca), which led to the blocking of imports of Brazilian meat by several importing countries.

The current rate of residual deforestation cannot be ignored, especially since it still remains one of the highest in the world. A large part of the residual deforestation pertains to the least capitalized small-scale farms, for whom public action has little to offer in terms of alternatives. These findings call for a redefinition of the issue of sustainability in a broader perspective, one that looks beyond the sole problem of deforestation, in order to design public action that reinserts the marginalized smallholder in the rural development project and enables a transition to sustainable land use, as other authors have already pointed out (Piketty et al., 20I5).

Moreover, the focus on the Amazon biome has led to a marginalization of social and environmental problems in the adjacent areas of the Cerrado. This vast biome, which covers about one-quarter of the country, is host to the richest biodiversity of any savanna in the world. However, it has been used for several years as a safety valve for the deforestation restrictions in the Amazon, a very worrying situation that we have already highlighted and which deserves more attention from the research community and environmental movements (Guéneau et al., 2015). Almost half of the Cerrado's original vegetation has already been converted into commercial crops and pastures.

In the context of neoliberal governmentality, many other environmental and social issues concerning the cattle value chain are under-addressed or dismissed, although they are equally relevant from a sustainability point of view, as underlined by various authors (Sambuichi et al., 20I2). For instance, the transition towards ever more intensive systems can lead to an increasing and often excessive use of pesticides and fertilizers in Brazil. Such an orientation would therefore not only result in local contamination of air, water and soil but also constitute a threat to the health of farmers and consumers of agricultural products. However, the narrowing neoliberal conception of the sustainable Brazilian cattle value chain does not consider the important issue of alternative production systems such as organic livestock.

\section{Theoretical Implications for Evaluation Research}

Various studies have already noted that robust evaluation frameworks are necessary to assess the effectiveness of the sustainability performance of value chains (Nelson and Martin, 20I4; Vermeulen and Kok, 20I2). Many studies have limited their focus to analyzing the impact of MSIs on sustainability using counterfactuals to compare certified and non-certified production units or those using mixed methods (for systematic overviews of the impact evaluation studies and the methods, see Nelson and Martin, 20I4, and Rangan, 20I7). Recent reviews of this literature found mixed results concerning the sustainability performance of MSIs (Oya et al., 20I7; Ruben, 20I7). Some impacts on the supply side are difficult to identify, especially spillover effects and other indirect effects, such as leakage effects. Certain aspects of sustainability - such as effects on food security - are not taken into account, especially when they are not incorporated into the standards when they are being formulated (Oosterveer et al., 20I4). This has led some researchers to focus their research on the conditions required for self-governance initiatives to be successful or on new evaluation methods that are based on the potential impact (Vermeulen, 20I5; Vermeulen and Metselaar, 20I5). In other words, since the literature on impact evaluation is still struggling to explain to what extent private initiatives 'change anything', some scholars are now asking to what extent a problem of sustainability can be solved effectively by private governance systems.

This shift towards 'actual versus aspirational' comparison within evaluation approaches, although promising, still appears problematic because these studies view the strategies and instruments implemented as a positive way of addressing challenges of sustainability without taking into account their neoliberal bias. Indeed, from this neoliberal perspective, the basic question of the evaluation is 'If we want a sustainable version of this kind of industrial and 
long-distance agriculture, what should be done?'. It seems to us that there is a need to strengthen evaluation research that distances itself from this vision. Evaluation research needs to focus on what kind of sustainable agriculture is desirable, and, after this, what can be done to sustain it. As Fouilleux et al. (20I7) affirm, it is not necessary to endorse the currently dominant productivist agricultural models based on genetically modified organisms and mineral fertilizers to feed nine billion people. Agricultural alternatives already exists, as suggested by the agroecology literature, even if, as Dumont and Bernuès (20I4) note, it has so far devoted little attention to animal production systems.

\section{Conclusion}

This analysis of the governance of the sustainable Brazilian cattle value chain in terms of neoliberal governmentality challenges the conventional explanation of private regulation as a set of mechanisms that allow the collective management of a social problem through the association of a variety of stakeholders. In the face of challenges of sustainability, some persuasive public measures have framed the behavior of the stakeholders within the cattle value chain. They have organized themselves through zero-deforestation agreements, certification and multi-stakeholder agreements within the GTPS, a range of neoliberal instruments that 'standardize' the way sustainable issues have to be addressed by private companies in order to access the global market.

The structuring effect of neoliberal governmentality is the way the conducts are conducted to the benefit of a certain category of Brazilian industrial interests - the major meat export companies - in order to maintain or improve their position in the global market. Thus, our interpretation of the role of the state in the private governance of sustainable value chains in Brazil's cattle sector goes beyond positing a simple struggle for power between the public and the private sectors.

The neoliberal instruments implemented to govern the Brazilian sustainable cattle value chain have focused on the highly publicized issue of deforestation in the Amazon biome. This governance has failed to fully attain its zerodeforestation goal and has been unable to address the many other challenges of sustainable development that are characteristic of meat production in Brazil. Future research on sustainability of the agri-food value chains in transition economies has to free itself from the neoliberal straitjacket that promotes a highly mechanized, industrialized and chemical-based agriculture to focus more on the development of alternative agricultural models such as agroecology.

\section{Acknowledgements}

This work has received the support of the French National Research Agency (ANR-II-CEPL-ooog - Project PRIGOUE: Privatizing Global Environmental Governance? The Roles of Multi-stakeholders Standards Initiatives for Global Environmental Change Mitigation), the European Union's Horizon 2020 Framework Programme for Research and Innovation under the Marie Skłodowska-Curie grant agreement 691053 (Project ODYSSEA) and the Brazilian research foundation of the State of Maranhão, FAPEMA (Edital no oo8/20I5 BPV Exterior).

\section{References}

Alves-Pinto HN, Newton P, Fernando L, Pinto G. 20I5. Reducing deforestation and enhancing sustainability in commodity supply chains: interactions between governance interventions and cattle certification in Brazil. Tropical Conservation Science 8(4): I053-I079.

Bartley T. 20I4. Transnational governance and the re-centered state: sustainability or legality? Regulation and Governance 8(I): 93-I09.

Bastos EB. 20I3. Working plan. Actions for 20I3 and 20I4. In Pathways for Sustainable Beef. GTPS: São Paulo; 7-8.

Bernstein S, Cashore B. 2007. Can non-state global governance be legitimate? An analytical framework. Regulation and Governance I(4): 347-37I. Brown W. 2003. Neo-liberalism and the end of liberal democracy. Theory and Event 7(I):

Cheyns E, Riisgaard L. 20I4. Introduction to the symposium. Agriculture and Human Values 3I(3): 409-423. 
Cheyns E, Daviron B, Djama M, Fouilleux E, Guéneau S. 20I7. The standardization of sustainable development through the insertion of agricultural global value chains into international markets. In Sustainable Development and Tropical Agri-chains, Biénabe E, Rival A, Loeillet D. (Eds.). Springer Netherlands: Dordrecht, The Netherlands; 283-303.

Coutinho A, Almeida C, Venturieri A, Esquerdo J, Silva M. 2013. Uso e Cobertura da Terra nas Áreas Desflorestadas da Amazônia Legal: TerraClass 2008. EMBRAPA-INPE: Brasília / São José dos Campos.

Djama M, Fouilleux E, Vagneron I. 20II. Standard-setting, certifying and benchmarking: a governmentality approach to sustainability standards in the agro-food sector. In Governing Through Standards: Origins, Drivers and Limitations, Ponte S, Gibbon P, Vestergaard J (eds). Palgrave Macmillan: Basingstoke.

Dumont B, Bernuès A. 20I4. Agroecology for producing goods and services in sustainable animal farming systems. Animal 8(8): I20I.

Foucault M (Ed). 2004a. Naissance de la Biopolitique Cours au Collège de France, 1978-1979. Seuil: Paris.

Foucault M. 2004b. Sécurité, territoire, population: cours au Collège de France, 1977-1978. Gallimard-Seuil: Paris.

Fouilleux E, Bricas N, Alpha A. 20I7. 'Feeding 9 billion people': global food security debates and the productionist trap. Journal of European Public Policy 24(II): $1658-\mathrm{I} 677$.

Fouilleux E, Daviron B. 2oıo. Néolibéralisme. In Dictionnaire de la globalisation: droit, science politique, sciences sociales, Arnaud A-J (ed). LGDJ-Lextenso: Paris; 389-396.

Gibbs HK, Munger J, L'Roe J, Barreto P, Pereira R, Christie M, Amaral T, Walker NF. 20I6. Did ranchers and slaughterhouses respond to zerodeforestation agreements in the Brazilian Amazon? Conservation Letters 9(I): 32-42.

Giessen L, Burns S, Sahide MAK, Wibowo A. 2016. From governance to government: the strengthened role of state bureaucracies in forest and agricultural certification. Policy and Society 35(I): 7I-89.

Glasbergen P. 20I6. Are Southern governments reclaiming sustainability standard-setting? In Meeting Sustainibility Goals: Voluntary Sustainability Standards and the Role of the Government: 2nd Flagship Report of the United Nations Forum on Sustainability Standards (UNFSS); 32-35.

Graz J-C, Nölke A. 2008. Transnational private governance and its limits. Routledge: London.

Guéneau S. 2009. Certification as a new private global forest governance system: the regulatory potential of the Forest Stewardship Council. In Non-State Actors as Standard Setters, Peters A, Föster T, Koechlin L, Fenner Zinkernagel G (eds). Cambridge University Press: Cambridge; $379-408$.

Guéneau S, Carneiro MS, Toni F. 20I5. The future of the Brazilian model of 'sustainable agricultural growth'. In A Planet for life - Building the future we want, Pachauri RK, Paugam A, Teresa R, Tubiana L. (Eds.). TERI Press: Delhi; II9-I32.

Guéneau S, Drigo IG. 20I3. Interações entre regulação pública e privada: a influência da certificação florestal privada sobre a renovação da ação pública na Amazônia brasileira. In Sociedade, Floresta e Sustentabilidade, Carneiro MS, Amaral Neto M, Ramos Castro EM (eds). Instituto Internacional de Educação do Brasil - NAEA: Belém, Brazil; I7-42.

Gulbrandsen LH. 20I4. Dynamic governance interactions: evolutionary effects of state responses to non-state certification programs. Regulation and Governance 8(I): 74-92.

Guthman J. 2007. The Polanyian way? Voluntary food labels as neoliberal governance. Antipode 39(3): 456-478.

Guthman J. 2008. Thinking inside the neoliberal box: the micro-politics of agro-food philanthropy. Geoforum 39(3): I24I-I253.

Hospes O. 20I4. Marking the success or end of global multi-stakeholder governance? The rise of national sustainability standards in Indonesia and Brazil for palm oil and soy. Agriculture and Human Values 3I(3): 425-437.

IBGE. 20I7. Produção da Pecuária Municipal 2016 Vol. 44: 47. IBGE, Diretoria de Pesquisas: Rio de Janeiro.

Jeanpierre L. 2006. Une sociologie foucaldienne du néolibéralisme est-elle possible? Sociologie et sociétés 38(2): 87-III.

Jorgensen DL. 1989. Participant Observation: A Methodology for Human Studies. Sage Publications: Newbury Park, USA.

Lambin EF, Meyfroidt P, Rueda X, Blackman A, Börner J, Cerutti PO, Dietsch T, Jungmann L, Lamarque P, Lister J. 20I4. Effectiveness and synergies of policy instruments for land use governance in tropical regions. Global Environmental Change 28: I29-140.

Lascoumes P. 2004. La Gouvernementalité: de la critique de l'État aux technologies du pouvoir. Portique I3/I4.

Loconto A, Fouilleux E. 20I4. Politics of private regulation: ISEAL and the shaping of transnational sustainability governance. Regulation and Governance 8(2): I66-I85.

Marx A, Cuypers D. 20I0. Forest certification as a global environmental governance tool: what is the macro-effectiveness of the Forest Stewardship Council? Regulation and Governance 4(4): 408-434.

Miller P, Rose N. I990. Governing economic life. Economy and Society I9(I): I-3I.

Neilson J, Pritchard B. 20I0. Fairness and ethicality in their place: the regional dynamics of fair trade and ethical sourcing agendas in the plantation districts of South India. Environment and Planning A 42: I833-I851.

Nelson V, Martin A. 20I4. Exploring issues of rigour and utility in Fairtrade impact assessment. Food Chain 4(I): I4-33.

Nelson V, Tallontire A. 20I4. Battlefields of ideas: changing narratives and power dynamics in private standards in global agricultural value chains. Agriculture and Human Values 3I(3): 48I-497.

Nepstad D, McGrath D, Stickler C, Alencar A, Azevedo A, Swette B, Bezerra T, DiGiano M, Shimada J, da Motta RS. 20I4. Slowing Amazon deforestation through public policy and interventions in beef and soy supply chains. Science 344(6I88): III8-II23.

Oosterveer P, Adjei BE, Vellema S, Slingerland M. 20I4. Global sustainability standards and food security: Exploring unintended effects of voluntary certification in palm oil. Global Food Security 3(3): 220-226.

Oya C, Schaefer F, Skalidou D, McCosker C, Langer L. 20I7. Effects of certification schemes for agricultural production on socio-economic outcomes in low- and middle-income countries: a systematic review, zie Systematic Review 34. International Initiative for Impact Evaluation (3ie): London.

Piketty M-G, Poccard-Chapuis R, Drigo I, Coudel E, Plassin S, Laurent F, Thâles M. 20I5. Multi-level governance of land use changes in the Brazilian Amazon: lessons from Paragominas, State of Pará. Forests 6(5): 1516-1536. 
Ponte S, Daugbjerg C. 20I5. Biofuel sustainability and the formation of transnational hybrid governance. Environmental Politics 24(I): 96-II4.

Rangan V. 20I7. Evaluating the Impact of Sustainability Standards. Lessons Learnt on Research Design and Methods from Three Impact Evaluations. ISEAL Alliance: London.

Ruben R. 20I7. Impact assessment of commodity standards: towards inclusive value chains. Enterprise Development and Microfinance 28(I/2): $82-97$.

Sambuichi R, Oliveira M, Silva A, Luedemann G. 20I2. A sustentabilidade ambiental da agropecuária Brasileira: impactos, políticas públicas e desafios, Texto para Discussão - Instituto de Pesquisa Econômica Aplicada (IPEA) 1782.

Schlesinger S. 20Io. Onde Pastar? O Gado Bovino no Brasil. FASE: Rio de Janeiro.

Schouten G, Bitzer V. 20I5. The emergence of Southern standards in agricultural value chains: a new trend in sustainability governance? Ecological Economics I20: $175-184$.

Schouten G, Glasbergen P. 2oII. Creating legitimacy in global private governance: the case of the Roundtable on Sustainable Palm Oil. Ecological Economics 70(II): I89I-I899.

Sending OJ, Neumann IB. 2006. Governance to governmentality: analyzing NGOs, states, and power. International Studies Quarterly 50(3): $65 \mathrm{I}-672$.

Vermeulen W. 20Io. Sustainable supply chain governance systems: conditions for effective market based governance in global trade. Progress in Industrial Ecology 7(2): $138-162$.

Vermeulen WJV. 2015. Self-Governance for Sustainable Global Supply Chains: Can it Deliver the Impacts Needed? Business Strategy and the Environment 24(2): 73-85.

Vermeulen W, Kok M. 20I2. Government interventions in sustainable supply chain governance: experience in Dutch front-running cases. Ecological Economics 83: 183-196.

Vermeulen WJV, Metselaar JA. 20I5. Improving sustainability in global supply chains with private certification standards: testing an approach for assessing their performance and impact potential. International Journal of Business and Globalisation I4(2): 226-250.

Walker NF, Patel SA, Kalif KA. 20I3. From Amazon pasture to the high street: deforestation and the Brazilian cattle product supply chain. Tropical Conservation Science 6(3): 446-467. 